\title{
Terra preta de índio: Commodification and Mythification of the Amazonian Dark Earths
}

Jens Soentgen, Klaus Hilbert, Carolin von Groote-Bidlingmaier, Gabriele Herzog-Schröder, Eije Erich Pabst, Sabine Timpf
Terra preta is a "hot" topic in the environmental sciences. From an anthropogenic soil type of local relevance, terra preta has been transformed by soil scientists into a techno-scientific object that helps to escape the global ecological crisis. The commodification goes along with a mythification that does not spare the scientific sphere.
Terra preta de índio: Commodification and Mythification of the Amazonian Dark Earths GAIA 26/2 (2017): 136-143

\begin{abstract}
This paper contributes to the history of terra preta research. It traces not only the history of science of Amazonian Dark Earths (terra preta de índio) but the history of knowledge of terra preta taking explicitly into account indigenous contributions. Five major phases are distinguished. In the beginning knowledge on terra preta was local indigenous knowledge. The scientific object "terra preta" was created in the context of archaeological research and has then been reframed as a carbon-sequestering soil in the context of the rising global warming debate in the early 1990s. This development led to a de-contextualization of terra preta and to commodification, giving rise to the biochar industry. Commodification included mythification of terra preta, stressing its ancient, prehistoric roots. Both processes - commodification and mythification - can also be found within the scientific sphere. This seems to indicate that not only terra preta has become a commodity, but that also research on terra preta shows signs of commodification.
\end{abstract}

Keywords

Amazonian Dark Earth, biochar, carbon storage, global warming, history of knowledge, indigenous knowledge, soil science, terra preta erras pretas (Portuguese for black earths) cover only small areas of usually two to 20 hectares in the lowland regions of Amazonia (sometimes much smaller). These soils - also named Amazonian Dark Earths - are mainly found in the vicinity of rivers. They are characterized by a significantly higher nutrient content compared with other Amazonian soil types (especially available phosphorus and nitrogen, but also other minerals like magnesium and calcium) and show a higher $\mathrm{pH}$ value, around 6.7, nearly neutral, which is maintained over a long-term period (Zech et al. 1979, Pabst 1993, pp.18-20). They are - as the name indicates - dark, contain large amounts of black carbon originating from incomplete combustion of organic materials ("biochar" in the anglophone literature), increased amounts of organic matter, and usually fragments of pre-Columbian potsherds. According to the current state of knowledge, they cover an area of 0.1 to about 0.3 percent or 6,000 to 18,000 squarekilometers of the wooded Amazonian lowlands (Woods and Denevan 2009, p. 1). They were formed between 2500 and 500 years before present, approximately. These soils are very valuable, as they show enduring fertility, and many of them are used for agriculture. The dominating primary forest soils in the Amazon lowlands (especially oxisols) are extremely nutrient-poor and acidic. They are not suited for long-term agriculture unless the nutrients are added via artificial fertilizers. The traditional form of cultivation in the Amazonian tropics is slash-and-burn. Through the burning of the biomass, which yields ashes and coal,
Contact: Prof. Dr. Klaus Hilbert (corresponding author) | Pontifícia Universidade Católica do Rio Grande do Sul (PUCRS) Programa de Pós Graduação em História | Av. Ipiranga, 6681, Prédio 03, Sala 415 | 90619-900 - Porto Alegre, RS. | Brazil | Tel.: +555133203534 | E-Mail: hilbert@pucrs.br

PD. Dr. Jens Soentgen | Environmental Science Center (WZU) | E-Mail: soentgen@wzu.uni-augsburg.de

Prof. Dr. Sabine Timpf | Institute of Geography | E-Mail: sabine.timpf@geo.uni-augsburg.de

both: University of Augsburg | Augsburg | Germany
Dr. Carolin von Groote-Bidlingmaier | Bavarian Environment Agency (LfU) | Augsburg | Germany | E-Mail: carolin.groote-bidlingmaier@Ifu.bayern.de

Dr. Gabriele Herzog-Schröder | Ludwig-Maximilians-Universität München | Department of Social and Cultural Anthropology | Munich | Germany | E-Mail: gabriele.herzog-schroeder@ethnologie.Imu.de

Dr. Eije Erich Pabst | Iranduba, Manaus | Brazil | E-Mail: post@eije.de

(C) 2017J. Soentgen et al.; licensee oekom verlag.

This is an article distributed under the terms of the Creative Commons Attribution License (http://creativecommons.org/licenses/by/3.0), which permits unrestricted use, distribution, and reproduction in any medium, provided the original work is properly cited. 
a fertile field is created. This field is abandoned when soil fertility declines.

The knowledge of the phenomenon, the properties and the localization of terras pretas in Amazonia is traditional indigenous knowledge (for a critical discussion of the term see Carneiro da Cunha 2009, pp. 10-26). This knowledge was, and in some respects remains, the basis for all scientific research on the topic. Even today, the normal way for researchers to "discover" new terra preta sites is to ask locals.

This is why a history of knowledge (Sarasin 2011) of Amazonian Dark Earth is necessary. A mere history of modern research on terra preta (see Woods and Denevan 2009), which only considers published articles, is insufficient, because from such an abbreviated history the conclusion might be drawn that only white (non-indigenous) researchers and entrepreneurs were the active producers of knowledge on terra preta.

\section{Indigenous Knowledge on Terra Preta}

Terra preta (as well as terra mulata - a more brownish type of terra preta) is a local term from the Brazilian Amazon lowlands, to which corresponding designations exist in Amerindian languages (Frutuoso do Vale Jr. et al. 2007). European travellers and researchers first learned about these soils through their native companions (Hilbert 1955, pp.11-19). Such soils were and are specifically searched for by the native groups in Amazonia, but also by other riverside dwellers, because all sorts of vegetation grow much better in these soils (Katzer 1903, p. 67, Mayntzhusen 1910, p. 462).

Indigenous knowledge of terra preta is much older than "white knowledge" of it. It constitutes the first and certainly most important phase of the history of knowledge of terra preta. One can assume that this knowledge was much more differentiated in the past than we know today. However, indigenous knowledge is poorly documented. It is reasonable to conjure that indigenous groups once not only knew the locations and the properties, but also had and have opinions concerning the origin of terra preta. Until today only very little ethnographic research has been conducted on this topic. How terra preta de indio could have (been) formed, and whether there still exists indigenous knowledge on soil management techniques that could have lead to the formation of terra preta was the question of Eije Erich Pabst's dissertation. A central motive of his research was to improve the livelihood in the Amazon lowlands. If it was known how terra preta arose out of the oxisol, then one would have the possibility to enhance the nutritional situation. However, none of the indigenous groups Pabst interviewed knew a "recipe" for the production of terra preta (Pabst 1993, pp. $142 \mathrm{f}$.). These findings do not refute the hypothesis that terra preta has been formed intentionally, as Pabst himself emphasizes. It is possible that this knowledge once existed, but then was lost during the population collapse in the centuries after the discovery of South America by Europeans, caused by persecution and the diseases brought in by them. Additionally, the indigenous populations were displaced from all favourable regions and were forced into a largely non-sedentary life. It is therefore possible that traditional know-how of how to intentionally produce terra preta, which had existed in pre-colonial times, was reduced and fragmented in the course of time, or was lost completely.

In contrast, Pabst's fieldwork revealed several indigenous ideas on the origin of terra preta. Besides the conjecture that the dark earth soils are of natural origin, there is also the opinion that they stem from the gods ${ }^{1}$, as well as the belief that other Indians made the earth (Pabst 1993, p. 72). Some interviewees stated that they did not know (Waiapi Indians, Pabst 1993, p. 104). Meanwhile, a similar investigation has also been undertaken at the Middle Caquetá River in Columbia (Peña-Venegas et al. 2016). Here, fire plays an important part in the speculations about the origin of terra preta (Peña-Venegas et al. 2016, p. 9).

Whether Amazonian Dark Earths were produced intentional$l y$ or rather formed unintentionally as a by-product of indigenous ways of life is still the subject of controversial debates. There are several arguments in favour of intentional production. The soil properties of terra preta locations are relatively homogeneous, which indicates active soil management. Ethnopedological research has shown that currently living Amerindian groups' lifestyle leads to the formation of black earth (Schmidt 2013). Even without this evidence, it would be plausible to presume that at least some of the indigenous groups formerly living in the Amazon consciously carried out soil management techniques by adding a combination of charcoal, ceramic sherds and organic material (human excrement). Considering the many inventions of the Amazon Indians (Nordenskiöld 1929, Soentgen and Hilbert 2012), it is highly unlikely that such a vital phenomenon should have totally escaped the people's conscious awareness prior to contact with Europeans. If organic waste is dumped at some location, it is clear that at some point someone will observe better growth of many plants in close proximity of such a compost-like site. A comparison with developments in other parts worldwide also supports the hypothesis. The first report on the use of charcoal in agriculture is found in a textbook-like treatise entitled Nogyo Zensho (Encyclopedia of Agriculture) written by Yasusada Miyazaki in 1697 (Ogawa and Okimori 2010, p. 489). Miyazaki describes, quoting from an older text published in China, that one should char waste, mix it with concentrated excreta and stock that mixture for a while. When this manure then is applied to the fields it is efficient for yielding any crop (Ogawa and Okimori 2010, p. 489). We see from this passage that the intentional use of charred organic material was probably of ancient origin in East Asia. In other words, modern scientific soil science is not necessary for the development of the forms of soil management that result over centuries in the formation of terra preta. Therefore it is plausible to assume that not only in East Asia, but also in South America people developed methods of soil improvement via biochar use, even if this knowledge was lost later.

\footnotetext{
1 According to a statement by Arawete Indians: "the forest god threw them down from heaven" (Pabst 1993, p. 72).
} 


\section{Selective Transfer of Indigenous Knowledge to Foreign Researchers}

The second phase is characterized by a selective transfer of knowledge about the phenomenon and the geographical locations of terra preta to European settlers and (later) researchers, mainly archaeologists. The transfer (and, at the same time, transformation) of local indigenous knowledge (on this notion Soentgen 2013) to Europeans (or descendants of them) is a process of historical significance that has already been thoroughly analysed by Gilberto Freyre in the second chapter of the book Casa Grande e Senzala (Freyre 2001). Freyre attributes the central role in this process of knowledge transfer to the "cunhã", the Tupí-Guaraní woman. Without such transfer the conquest of South America by European settlers could not have taken place, as conquest and settlement require knowledge how to survive in a new and therefore unknown environment (geographical and technical knowledge, knowledge of plants, animals, people, languages, etc.) (Friederici 1925, pp. 151161, 187 f., see also Posey 2000).

Correspondingly, European researchers learned about the dark earths from indigenous people. Their interest in these earths was motivated firstly by the discovery of potsherds of pre-Columbian Indian cultures in these soils. "Onde há terra preta há 'careta" where there is dark earth, there are (anthropomorphic) clay fig- ures and zoomorphic appendages (Hilbert 1955, p. 13). Therefore, the locals often refer to theses soils as terra preta de indio - black earth of the (American) Indian. The archaeologists who entered the Amazon from the late $19^{\text {th }}$ century onwards were looking for new sites of pre-Columbian settlements. To them, terra preta within a matrix of oxisols was an indicator of ancient settlements. They were interested in ceramics, not in earths. And the ceramics were found in terra preta sites (figure 1).

The existence of the fertile Amazonian Dark Earths has farreaching significance for the reconstruction of the history of the Americas, since it forces scholars to revise the estimates of the number of inhabitants of Amazonia before 1492. Currently a precolonial population of eight to ten million is considered plausible, based on estimates of terra preta acreages in Amazonia, which is much more than formerly estimated (Clement et al. 2015, see also Smith 1980).

This fits the observations of Conquistador Francisco de Orellana (1511 to 1546), whose chronicler Gaspar de Carvajal reports that they had sighted numerous huge settlements in this first expedition along the Amazon in 1542, especially in the region below and above the confluence of the Rio Negro (Carvajal 1894, pp. 41-49). Retrospectively Carvajal praised the extraordinarily intelligent and inventive people of the Amazon and their wonderful works (Carvajal 1894, p. 81).

FIGURE 1: Indigenous ceramics from a terra preta site are analyzed and discussed at the Museo Emílio Goeldi in Belém (Pará).

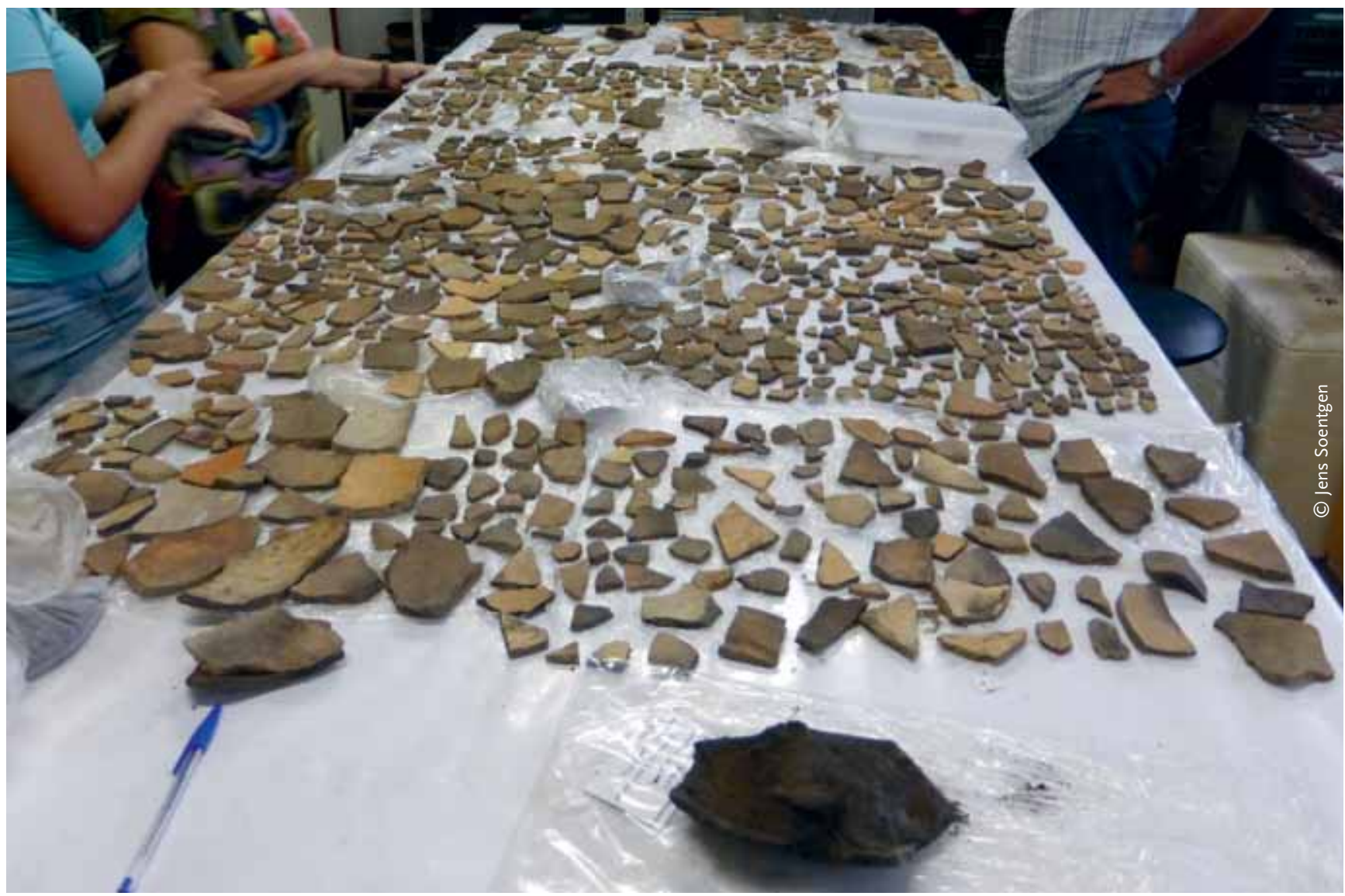




\section{The Scientific Characterization of terra preta de índio}

Until the first half of the $20^{\text {th }}$ century, "white knowledge" of terra preta was restricted to a positivistic knowledge of certain properties and geographical distribution plus vague ideas on the origin of these earths. The German-Brazilian ethnologist and archaeologist Curt Nimuendajú (1883 to 1945; on Nimuendajú's scientific work and life see Baldus 1946, Hartmann 1981) went beyond this state by developing an empirical theory of the formation of terra preta (Nimuendajú-Unkel 1914).

Nimuendajú postulated that wherever a certain earth was found, that is, what is called terra preta de indio in Amazonia, ceramic fragments of earlier cultures would also be found. Following this premise, Nimuendajú discovered the remains of 63 previously unknown indigenous settlements in the vicinity of Santarém at the confluence of the Rio Tapajós and the Amazon. line microenvironment to symbiotic microorganisms and to nitrogen-fixing bacteria in the soils and therefore enhances plant growth (figure 2, p. 141), especially in tropical soils (Ogawa and Okimori 2010, p. 497).

\section{Synthetic Black Earth as Climate Saviour}

The fourth phase of the history of knowledge of terra preta starts with the idea that Amazonian Dark Earth could be produced synthetically, and that such a production might mitigate major social and environmental problems. In 1992 the Dutch soil scientist Wim Sombroek, who had already devoted his doctoral thesis to the soils of the Amazon (Sombroek 1966, pp. 174-176), outlined the idea to use biochar in order to sequester carbon, which would be decisive for the further story of terra preta (Sombroek 1992). He proposed to produce terra preta nova (new black earth) through the

\section{The local phenomenon terra preta de índio was reframed into the artificially "manufacturable" substance and commodity terra preta nova that one now can buy by the sackful in many garden centers.}

In a letter written in 1945 to the German-Brazilian ethnologist Herbert Baldus (published in Baldus 1951, pp. 2 f.), he outlined, a few months before his death, his thoughts. ${ }^{2}$ Nimuendajú concluded from a lucid interpretation of the spatial distribution of terras pretas that they could not have been formed from the remnants of sediments of lakes nor of volcanic ashes but that they are anthropogenic soils. Intentionally or unintentionally they had been produced by indigenous populations having once settled there. Nimuendajú stated that all terras pretas in Amazonia were of indigenous origin. Their formation, he explained, was due to the burning of wood in hearths, not to slash-and-burn. He also generalized that all dark earths were archaeological sites, because all dark earths of Amazonia were made by people. He thereby positioned himself in opposition to the prevailing interpretation that presumed a natural genesis of terras pretas (Katzer 1903, p. 68).

Based on the thoughts of Nimuendajú, in the early 1980s the natural scientific research of the terras pretas started with the investigations of Eije Erich Pabst and Gerhard Bechtold. For the first time they showed that (and how) the black earths differ chemically from the reddish oxisols common in Amazonia: terras pretas have, as already mentioned, a significantly higher $\mathrm{pH}$ value and contain more organic substances, parts of which stem from human faeces (Birk et al. 2011), more nitrogen and more phosphorus (Zech et al. 1979, Pabst 1993, pp.18-20). The characteristic portion of charcoal had already been highlighted by Nimuendajú.

Today, the scientific characterization and explanation of the properties of terra preta is the subject of a world-wide research community. It is assumed that charcoal offers a favourable alka- deliberate introduction of plant charcoal into nutrient-poor soils to enhance their long-term characteristics. Sombroek foremost followed the goal of giving the inhabitants of Amazonia, and of the tropics in general, an instrument to achieve greater harvests through reactivation of ancient techniques of soil-amendment (Sombroek et al. 2002). On the other hand, he argued, a significant contribution to the fight against man-made global warming could be made. This combination of terra preta with the issue of climate change brought terra preta onto the international agenda. Sombroek explained that the synthetically produced terra preta no$v a$ could help in the mitigation of climate change because it stored carbon (on studies supporting this claim see Ogawa and Okimori 2010, p. 496). Through the introduction of biochar into the soil, carbon could be sequestered, because the carbon in the charcoal is not as easily mobilized to carbon dioxide or methane as is the carbon in organic material. Charcoal is more stable than are organic materials that are formed out of carbon compounds.

Sombroek generated an international researcher community. He gave it a new narrative, which roots the carbon-sequestering terra preta nova in pre-colonial times, and an emblem created by himself (Woods et al. 2009, backside cover), which alludes to indigenous designs and fits to the narrative. He thereby provided soil science, a discipline usually standing in the shadow, with unex-

\footnotetext{
2 It might be considered as a basic document of that research even if in the modern terra preta research it has lapsed into obscurity (e.g., it is not mentioned in the chronology of Woods and Denevan 2009).
} 
pected media attention and made it more competitive with respect to fundraising. Sombroek did not only create a new research agenda, but also a convincing story. Here the climate-affecting trace gases generated by the industrial civilization, there the solution for the problem: a very specific man-made earth, whose secret we owe to the indigenous people of the rain forest living in harmony with nature (for a critique of the image of the eco-friendly Indian see Krech 1999, on Krech see Andrej 2015, pp. 51-59).

\section{Terra preta nova as Commodity and Myth in Industry and Science}

Sombroek's vision has since been put into practice. ${ }^{3}$ In a fifth discourse phase, terra preta was reframed as a commodity, and the research on terra preta likewise shows signs of commercialization. Terra preta nova is the object of a rapidly growing industry that has made a product out of the Amazonian soil that one now can buy by the sackful in many garden centers. In July 2006, the International Biochar Initiative ${ }^{4}$ was founded, whose goal is to support research on and commercialization of biochar suitable for the manufacture of black earth. The use of industrially made biochar in agriculture should now, according to the activists, increase climate protection through long-term carbon sequestration as well as soil fertility. Lobbying work is being conducted in the political as well as in the economic sphere. One goal is that biochar, as sequestered carbon, is acknowledged as an effective means of storing carbon and takes its place in global political climate decisions, particularly in the Kyoto protocol and in subsequent treaties (see the critical discussion in Bruges 2009, pp. 100-114).

The elemental carbon in the form of charcoal became more and more the central focus, probably because of the attention given to the climate issue. The climate-saving terra preta nova is in many respects different from the terra preta de indio. First and foremost, it is a manufactured product while the original terra preta is a special soil type that is the stable result of an anthropogenic in-situ transformation of an oxisol, a soil type that formed over thousands of years in tropical regions out of different rock types. Second, the commodity terra preta nova is a de-contextualized substance that can be commercialized, and that resembles Amazonian Dark Earths in some aspects only. This terra preta nova can be produced anywhere through a technical process. Although it has been shown that the porous ceramic components of the ancient potsherds also have a positive function as a water reservoir (Macedo et al. 2008) and alter the course of water in the soils, they are excluded of the usual definition and practice of terra preta nova research and of the usual terra preta production maybe because they are irrelevant to the global-warming frame. This alteration in the definition induces a major semantic shift: a certain type of local soil is reframed into an artificially "manufacturable" substance and commodity. ${ }^{5}$ To put a fine point on the matter one could say that the local phenomenon terra preta de indio became a terra preta de gringo, a dark earth of non-place-based, internationally active researchers and businessmen.
Simultaneously with the commodification of terra preta nova a myth has been constructed. This myth frequently surfaces in the fifth phase of terra preta knowledge history. The myth constructs a new, synthetic context for the de-contextualized substance. It has the function of a sales pitch and is a typical supplement of commodities (Haug 1986). Thus, a "black revolution from the rain forest" has been launched, which shows the "way out of the worldwide climate and hunger crisis" (see Scheub et al. 2014, book jacket text). German producers utilize the myth in order to market their high-priced garden soil. ${ }^{6}$

Similar visions are also found in scientific papers, usually in the abstract or in the introduction. This indicates that not only terra preta nova became a commercial product, but also the research on terra preta is being commercialized in the era of "academic capitalism” (Münch 2014). Huge grants (e. g., a European Research Council Consolidator Grant of 1,723,004.97 euros from 2014 to 2018) for terra preta research have been won in Europe and North America with promises of mitigation of global warming and promotion of "sustainability". Research must sell nowadays. And it sells better if it tells fascinating myths.

For one of the most renowned terra preta researchers in Germany, Bruno Glaser, terra preta can contribute simultaneously to three of the Millennium Development Goals defined by the United Nations, in that it fights desertification, binds atmospheric $\mathrm{CO}_{2}$ and thereby fights global warming, as well as helping maintain biodiversity hotspots in tropical rain forests (Glaser 2007, p. 187). The large-area use of terra preta would reduce the pressure on primary forests and thus stop further degradation of the rain forest, and at the same time protect the climate. The US-American soil researcher Johannes Lehmann likewise considers the incorporation of biochar in the soil to be a "win-win approach" (Lehmann 2009, see also Lehmann 2007), and his colleague David A. Laird even speaks of a "charcoal vision: a win-win-win scenario for simultaneously producing bioenergy, permanently sequestering carbon while improving soil and water quality" (Laird 2008). Biochar production can become lucrative, especially if the manufacture and incorporation of biochar becomes part of the emission certificate market as $\mathrm{CO}_{2}$ sequestration.

Although surely not every scientific paper on terra preta contains such forms of persuasive language, the above examples are not exceptions. In many scientific papers terra preta nova is framed as a re-enactment of past cultural techniques. Thereby the idea

\footnotetext{
3 Whether this is achieved in a manner that would have satisfied him, is an open question.

4 www.biochar-international.org

5 Through this change in meaning, the newly defined terra preta can be industrially produced in a manner similar to what the Bavarian writer Walter von Molo once imagined in his Murnau Diaries as "earth factories" that "would produce wonderful wheat soil or whatever was desired, that then would be poured out over swamps, deserts, barren or stony areas of all types. Rains of earth would be allowed to occur with great transport aircraft, earth cloudbursts" (von Molo 1959, p. 153).

6 The company Palaterra advertises with the slogan: "The gold of the earth after the example of the Índios" (Palaterra 2014).
} 


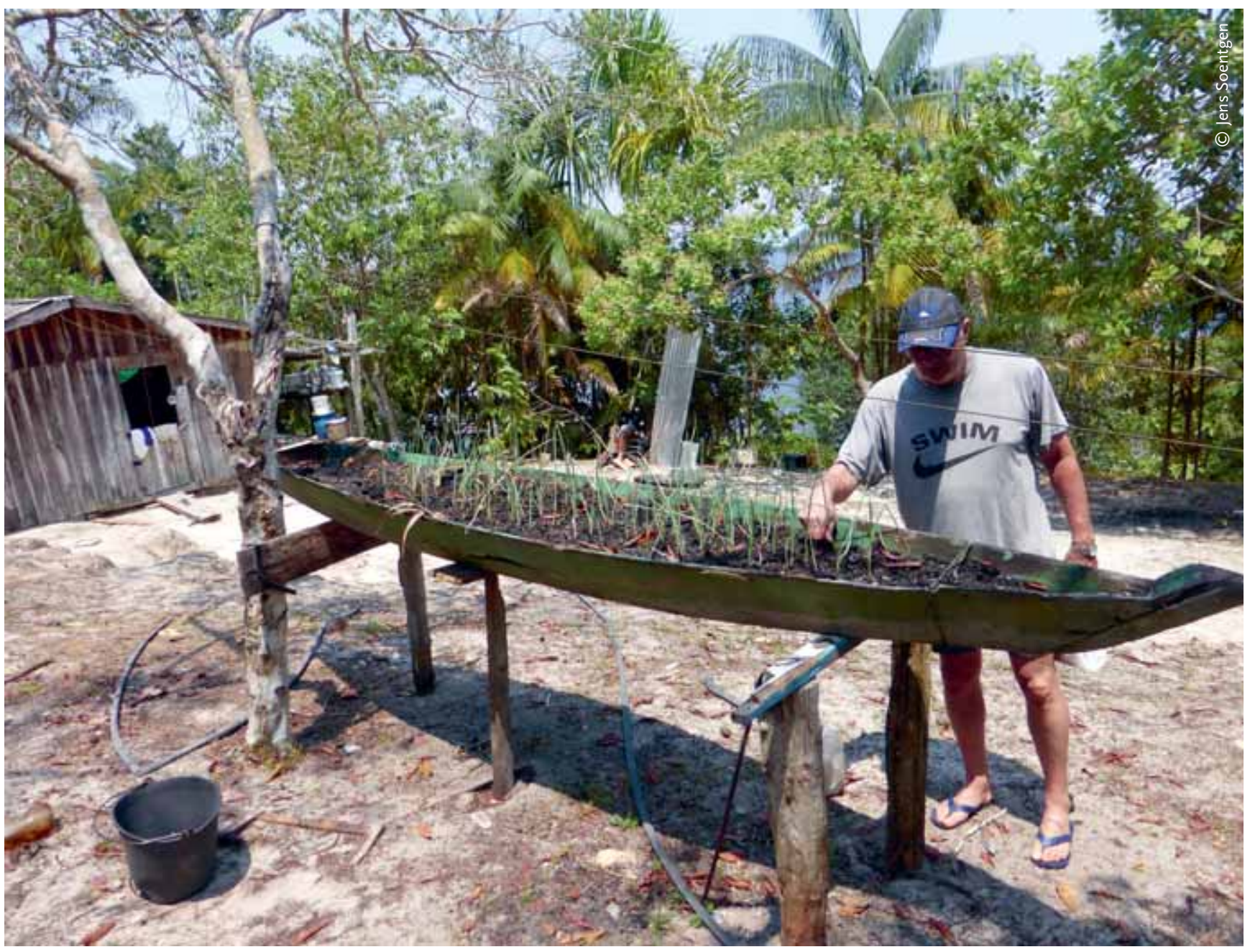

FIGURE 2: Riparians in Amazonia still use hearth ash and charcoal to enhance the fertility of their onion beds (Rio Negro).

gains additional persuasive power. Not only is a strategic vision being formulated, but a narrative is constructed that works at the same time as a research-directing paradigm. For such narratives and meaningful tales, it is characteristic to frame the salvation as a return of something ancient, prehistoric. Such narratives reach back, telling the story of prehistorical conditions, people and gods, in order to orient and motivate the action of present-day protagonists (Wülfing 1997, pp.159f., on the term "myth" see also Schmitz 2013). In our case, it is the pre-Columbian Indian who was in possession of the secret to make fertile soil out of infertile ground. This ability of traditional societies was, according to this frame, not only based on knowledge, but on wisdom. Therefore it is valid to reactivate it now for the purpose of finding a way out of the ecological crisis.

The mythicizing is problematic in the scientific context. It suggests that a (technical) way out of the problems mentioned has been found - terra preta nova. However, that is doubtful. The main stumbling block for an effective fight against further and accelerated global warming is not first and foremost technical, but rather of a political nature. There are many technical options, but none of them will stop or slow down global warming, because the global political will to implement them is limited (Soentgen 2016). The mythicizing nevertheless fulfills functional purposes. For one thing, it might have the function of convincing funding agencies, but then motivating the research community and attracting young researchers could prove to be more impactful (see Frese 2000 on the function of narratives in groups). For instance, a report on a terra preta symposium, published in Nature, commented on a meeting of soil scientists who are researching terra preta: "More than one eye in the room had a distinctly evangelical gleam" (Marris 2006, p. 624). The same journal is supportive of spinning the myth further. Cernansky (2015) praised terra preta as a substance of hope that is not only a possible remedy for climate change, but also a nutrient and water reservoir and even an absorbing medium for toxic substances. He retells the myth of the ancient Amazonian origins: "Although it is just starting to catch on with farmers today, biochar has ancient roots. Hundreds of thousands of years (sic!) ago, residents of the Amazon produced it by heating up organic matter to create rich, fertile soils called terra preta" (Cernansky 2015, p. 259). 
By the end of March 2017, 4,019 scientific publications had been published that referred to terra preta or biochar. ${ }^{7}$ Terra preta inspired research in many areas, for example on novel methods of wastewater treatment (Rakelmann et al. 2009). But mostly it is framed as a carbon sink. The euphoria is not groundless, for example, if biochar replaces peat, it might contribute to climate protection, especially in Europe (Kammann et al. 2010, pp. 52-54). Nevertheless, some claims may prove exaggerated. In a study published in 2011 it has been criticized that up to then only few field studies had proved that the carbon particles really remain in the soil and that the carbon bonding is not (over)compensated by other processes (Ernsting 2011, pp. 8-12). In addition, health considerations come into play, at least if terra preta is produced by farmers on a small scale without state-of-the-art technology: not only smoke (see for a new analysis of smoke of burned plants Iinuma et al. 2007), but also other products of the pyrolysis processes (i.e., organic compounds that remain in the charcoal) can be a danger to health. In addition, other uses for biomass might compete with biochar (Scholz et al. 2014, pp. 55-60, Lai 2007).

It should also be noted critically that mainly large companies would profit from the integration of terra preta nova and, respectively, biochar in the $\mathrm{CO}_{2}$ markets (Ernsting 2011, pp. 18f.). Also, it may not be easy to confirm that biochar is sustainably produced and does not originate from illegal deforestation (Bruges 2009, p. 117). Consequently, the Biochar activists are criticized by other nongovernmental organizations, particularly by Biofuelwatch ${ }^{8}$ (see Bates 2010, pp. 169-174).

\section{Outlook}

In Germany, terra preta (and terra mulata) are registered as protected names or trademarks (registered with the Terra Preta $\mathrm{GmbH}$, headquartered in Berlin). However, it should be stressed that the concepts and the expressions terra preta (and terra mulata) are not products of European creativity. They are the intellectual achievements of the people of Amazonia. The modern terra preta research would have hardly ever started without indigenous knowledge. This is not only valid for the knowledge of the concrete sites and characteristics of terra preta. Also, the knowledge of the special suitability of terra preta for plant cultivation originates in traditional indigenous knowledge. It may still be controversial whether the ancestors of Amazonian natives living today produced terra preta intentionally, but there are observations that support this claim (Schmidt 2013, Hecht and Posey 1989).

Who benefits from research on terra preta? Sombroek's terra preta nova was intended to help local inhabitants of Amazonia and mankind at the same time. The local concrete benefit that Sombroek wanted to achieve has been lost sight of in the course of the transformation of terra preta de índio to a carbon-based, only glob-

7 Own online research via ISI Web of Science, March 23, 2017.

8 www.biofuelwatch.org.uk/wp-content/uploads/Biochar-3-pager7.pdf ally relevant terra preta do gringo that is defined and produced not by locals but by translocal experts. To the authors of this paper it seems appropriate to make the cognitive and maybe also the financial gain to which terra preta nova leads more effective for the Amazonia's present-day inhabitants.

We would like to thank the German Academic Exchange Service (DAAD) and Capes (Brasília) for funding research on terra preta and three anonymous reviewers for valuable remarks and suggestions.

\section{References}

Andrej, M. 2015. Die Konstruktion von traditional ecological knowledge: Eine kritische Analyse wissenschaftlicher Umwelt- und Naturschutzdiskurse. Vienna: Institute of Social Ecology. www.uni-klu.ac.at/socec/downloads/ WP162_Online.pdf (accessed September 6, 2016).

Baldus, H. 1946. Curt Nimuendajú, 1883-1945. American Anthropologist, N. S., 48: $238-243$.

Baldus, H. 1951. Tonscherbenfunde in Nordparana. Archiv für Völkerkunde 6: 1-19.

Bates, A. 2010. The biochar solution: Carbon farming and climate change. Gabriola Island, BC: New Society.

Birk, J. J., W. G. Teixeira, E. G. Neves, B. Glaser. 2011. Faeces deposition on Amazonian anthrosols as assessed from 5ß-stanols. Journal of Archaeological Science 38: 1209-1220.

Bruges, J. 2009. The biochar debate: Charcoal's potential to reverse climate change and build soil fertility. Schumacher Briefings 16. Dartington: Green.

Carneiro da Cunha, M. 2009. "Culture" and culture: Traditional knowledge and intellectual rights. Chicago: Prickly Paradigm.

Cernansky, R. 2015. State-of-the-art soil. Nature 517: 258-260.

Clement, C. R. et al. 2015. The domestication of Amazonia before European conquest. Proceedings of the Royal Society of London B 282: 20150813. doi: 10.1089/rspb.2015.0813.

de Carvajal, Fr. G. 1894. Descubrimiento del Río de las Amazonas según la relación hasta ahora inédita de Fr. Gaspar de Carvajal con otros documentos referentes à Francisco de Orellana y sus companeros publicados. Por José Toribio Medina. Sevilla: Imprenta de E. Rasco, Bustos Tavera.

Ernsting, A. 2011. Biochar - a climate smart solution? Aachen: Misereor.

Frese, J. 2000. Intellektuellen-Assoziationen. In: Kreise, Gruppen, Bünde. Zur Soziologie moderner Intellektuellenassoziation. Edited by R. Faber, C. Holste. Würzburg: Königshausen und Neumann. 441-462.

Freyre, G. 2001. Casa-grande e senzala. Formação da família brasileira sob o regime de economia patriarchal. Lisboa: Colecção livros do Brasil.

Friederici, G. 1925. Der Charakter der Entdeckung und Eroberung Amerikas durch die Europäer. Einleitung zur Geschichte der Besiedlung Amerikas durch die Völker der Alten Welt. Erster Band. Stuttgart: Friedrich Andreas Perthes.

Frutuoso do Vale Jr., J., C. Schaefer, J. A. Vieira da Costa. 2007. Etnopedologia e transferência de conhecimento: Diálogos entre os saberes indígena e técnico na terra indígena Malacacheta, Roraima. Revista Brasileira das Ciências do Solo 31: 403-412.

Glaser, B. 2007. Prehistorically modified soils of central Amazonia: A model for sustainable agriculture in the twenty-first century. Philosophical Transactions of the Royal Society B 362: 187-196.

Hartmann, T. 1981. O enterro de Curt Nimuendajú (1883-1945). Revista do Museu Paulista 28: 187-190.

Haug, W. F. 1986. Critique of commodity aesthetics: Appearance, sexuality, and advertising in capitalist society. Minneapolis: University of Minnesota Press.

Hecht, S. B., D. A. Posey. 1989. Preliminary results on soil management techniques of the Kayapó Indians. In: Resource management in Amazonia: Indigenous and folk strategies. Advances in economic botany. Volume 7. Edited by D. A. Posey, W. Balée. New York: New York Botanical Garden. 174-188.

Hilbert, P.P. 1955. A cerâmica arqueológica da região de oriximiná. Belém: Museu Goeldi.

linuma, Y. et al. 2007. Source characterization of biomass burning particles: The combustion of selected European conifers, African hardwood, savannah grass, and German and Indonesian peat. Journal of Geophysical Research 112. doi: 10.1029/2006JD007120. 
Kammann, C., Y. Kühnel, C. von Bredow, J. Gößling. 2010. Abschlussbericht des Projekts C-Sequestrierungspotential und Eignung von Torfersatzstoffen, hergestellt aus Produkten der Landschaftspflege und Biochar. Justus-LiebigUniversität Gießen, Institut für Pflanzenökologie.

Katzer, F. 1903. Grundzüge der Geologie des unteren Amazonasgebietes (des Staates Pará in Brasilien). Leipzig: Max Weg.

Krech III, S. 1999. The ecological indian: Myth and history. London: Norton.

Lai, R. 2007. Managing soils for food security and climate change. Journal of Crop Improvement 19: 49-71.

Laird, D. A. 2008. The charcoal vision: A win-win-win scenario for simultaneously producing bioenergy, permanently sequestereing carbon, while improving soil and water quality. Agronomy Journal 100/1: 178-181.

Laird, D. A., N. P. Rogovska, M. Garcia-Perez, H. P. Collins, J. D. Streubel, M. Smith. 2011. Pyrolysis and biochar: Opportunities for distributed production and soil quality enhancement. In: Sustainable alternative fuel feedstock opportunities, challenges and roadmaps for six U.S. regions. Edited by R. Braun, D. L. Karlen, D. Johnson. Proceedings of the Sustainable Feedstocks for Advanced Biofuel workshop. www.swcs.org/documents/ resources/Chapter_16_Laird_Pyrolysis_and_Bi_96E09F2679C2B.pdf (accessed May 4, 2017).

Lehmann, J. 2007. A handful of carbon. Nature 447: 143-144.

Lehmann, J. 2009. Biological carbon sequestration must and can be a win-win approach. Climatic Change 97: 459-463.

Macedo, R. S., W. G. Teixeira, G. C. Martins. 2008. Efeito da concentracao de fragmentos cerâmicos na retenção de água do solo em amostras de Terra preta de Índio na Amazônia Central - Brasil. Manaus: Embrapa Amazônia Ocidental.

Marris, E. 2006. Putting the carbon back: Black is the new green. Nature 442: $624-626$.

Mayntzhusen, F.C. 1910. Über vorkolumbianische Siedelungen und Urnenfriedhöfe der Guarani am Alto Parana. Proceedings - International Congress of Americanists XVII: 459-469.

Münch, R. 2014. Academic capitalism. Universities in the global struggle for excellence. London: Routledge.

Nimuendajú Unkel, C. 1914. Die Sagen von der Erschaffung und Vernichtung der Welt als Grundlagen der Religion der Apapocúva-Guaraní. Zeitschrift für Ethnologie 46: 284-403.

Nordenskiöld, E. 1929. The American indian as an inventor. Journal of the Royal Anthropological Institute of Great Britain and Ireland 59: 273-309.

Ogawa, M, Y. Okimori. 2010. Pioneering works in biochar research, Japan. Australian Journal of Soil Research 48: 489-500.

Pabst, E. E. 1993. Terra preta. Ein Beitrag zur Genese-Diskussion auf der Basis von Geländearbeiten von Tupí-Völkern Amazoniens. Dissertation, Universität Kassel.

Palaterra. 2009. Informationsprospekt zu: The Royal Society. Geoengineering the climate: Science, governance and uncertainty. Hengstbacherhof: Palaterra.

Peña-Venegas, C. P., T. J. Stomph, G. Verschoor, J. A. Echeverri, P. C. Struik. 2016. Classification and use of natural and anthropogenic soils by indigenous communities of the upper Amazon region of Colombia. Human Ecology 44: 1-15.

Posey, D. A. 2000. Biodiversity, genetic resources, and indigenous peoples in Amazonia: (Re)Discovering the wealth of traditional resources of native Amazonians. In: Amazonia at the crossroads. The challenge of sustainable development. Edited by A. Hall. London: Institute for Latin American Studies. 188-204.

Rakelmann, U. et al. 2009. Die Abwasserentsorgung als Kohlenstoffsenke? Die Hydrothermale Karbonisierung. Wasserwirtschaft Wassertechnik 6/2009: 44-50.

Sarasin, P. 2011. Was ist Wissensgeschichte? Internationales Archiv für Sozialgeschichte der Literatur 36: 159-172.

Scheub, U., H. Pieplow, H.-P. Schmidt. 2014. Terra preta. Die schwarze Revolution aus dem Regenwald. München: oekom.

Schmidt, M. 2013. Amazonian dark earths: Pathways to sustainable development in tropical rainforests? Boletim do Museu Paraense Emílio Goeldi. Ciências Humanas 8/1: 11-38.

Schmitz, C. 2013. Mythos. A. Begriffsbestimmung. In: Reallexikon für Antike und Christentum. Edited by G. Schöllgen et al. Stuttgart: Anton Hiersemann. $471-474$.
Scholz, S. M., T. Sembres, K. Roberts, T. Whitman, K. Wilson, J. Lehmann. 2014. Biochar systems for smallholders in developing countries. Leveraging current knowledge and exploring future potential for climate-smart agriculture. Washington, D. C.: World Bank.

Smith, N.J.H. 1980. Anthrosols and human carrying capacity in Amazonia Annals of the Association of American Geographers 70/4: 553-566.

Soentgen, J. 2013. Die Rolle indigenen Wissens in der Geschichte des Kautschuks. Technikgeschichte 80/4: 295-324.

Soentgen, J. 2016. Pie in the Sky. Wider den umweltpolitischen Utopismus. Merkur 70/804: 85-92.

Soentgen, J., K. Hilbert. 2012. Präkolumbianische Chemie. Chemie in unserer Zeit 46: 322-334.

Sombroek, W. 1966. Amazon soils. A reconnaissance of the soils of the Brazilian Amazon region. Wageningen: Pudoc.

Sombroek, W. 1992. Biomass carbon storage in the Amazon ecosystems. Interciencia 17: 269-272.

Sombroek, W. et al. 2002. Terra preta and terra mulata, pre-Colombian kitchen middens and agricultural fields, their sustain-ability and replication. Paper presented at the $1^{\text {th }}$ World Congress of Soil Science. Bangkok, August 14-21.

von Molo, W. 1959. Wo ich Frieden fand. Erlebnisse und Erinnerungen. München: Braun und Schneider.

Woods, W. I., W. M. Denevan. 2009. Amazonian dark earths: The first century of reports. In: Amazonian dark earths. Wim Sombroek's vision. Edited by W. I. Woods, W. G. Teixeira, J. Lehmann, C. Steiner, A. WinklerPrins, L. Rebellato. Dordrecht: Springer. 1-14.

Woods, W. I., W. G. Teixeira, J. Lehmann, C. Steiner, A. WinklerPrins, L. Rebellato (Eds.). 2009. Amazonian dark earths. Wim Sombroek's vision. Dordrecht: Springer.

Wülfing, W. 1997. Mythen und Legenden. In: Geschichtsdiskurs. Band 3: Die Epoche der Historisierung. Edited by W. Küttler, J. Rüsen, E. Schulin. Frankfurt am Main: Fischer. 159-172.

Zech, W., E. Pabst, G. Bechtold. 1979. Analytische Kennzeichnung der Terra preta do índio. Mitteilungen der Deutschen Bodenkundlichen Gesellschaft 29: 709-716.

Submitted July 14, 2016; revised version accepted May 19, 2017.

\section{Jens Soentgen}

Born 1967 in Bensberg, Germany. Studies in chemistry, philosophy and sociology, PhD in philosophy. 2015 habilitation and venia legendi for philosophy. Since 2002 scientific director at the Environmental Science Center of Augsburg University and adjunct professor of philosophy at Memorial University in St. John's, Canada. Research interests: science and technology studies, environmental philosophy and interdisciplinary environmental research. Member of GAIA's Editorial Board.

Klaus Hilbert

Born 1953 in the Amazon region. $1984 \mathrm{PhD}$ from the University of Marburg, Germany. Since 1990 professor of archaeology at the Catholic University of Rio Grande do Sul (PUCRS), Brazil. Formerly coordinator of the PhD Program of Iberian-American History, presently coordinater of a research group on Material Culture Studies at the Catholic University. Research interests: prehistory of the Amazon and the Rio de la Plata region.

Eije Erich Pabst

Born 1948 in Bad Kissingen, Germany. Studies in geography, ecology, and soil sciences. 1989 to 1991 terra preta research in six different Indian areas in the Brazilian Amazon, funded by German Academic Exchange Service (DAAD), published in his PhD thesis. Since 1989 social and environmental projects in the Amazon, consultant on Amazon environmental and social issues, especially on terra preta. 